\title{
Development and content validity of the Abilitator: a self-report questionnaire on work ability and functioning aimed at the population in a weak labour market position
}

Miia Wikström ${ }^{1 *}$, Heidi Anttila², Minna Savinainen ${ }^{3}$, Anne Kouvonen ${ }^{4,5,6}$ and Matti Joensuu ${ }^{1}$

\begin{abstract}
Background: The unemployed have lower work ability and poorer health than the employed. This situation deteriorates when unemployment continues. The long-term unemployed often have co-morbidities and face many other challenges. This increases the need for a multidimensional assessment of work ability and functioning in different service settings. In this study, we describe the development and analyse the content validity of the Abilitator, a self-report questionnaire on work ability and functioning for those in a weak labour market position.
\end{abstract}

Methods: The Abilitator was developed in 2014-2017. Its construct was assessed by members of academic expert panels $(n=30)$, practical expert panels of professionals $(n=700)$ and target group clients $(n=28)$. The structure and the content of the questionnaire was co-developed in 29 workshops and adjusted twice based on the expert panels' feedback. The Abilitator was also implemented among target group clients $(n=3360)$ in different services and projects. During its development the Abilitator was linked to the International Classification of Functioning, Disability and Health (ICF). The content validation process followed the guidelines recommended by the Consensus-based Standards for the selection of health Measurement Instruments (COSMIN) panel.

Results: The construct of the Abilitator combines the multidimensional and biopsychosocial models of work ability and functioning. It also includes aspects of social inclusion and employability. It evaluates social, psychological, cognitive and physical functioning, and the ability to cope with everyday life. The content of these concepts was validated by the academic and practical expert panels. The Abilitator's 79 ICF codes covered 57\% of the Generic, 77\% of the Brief Vocational Rehabilitation, and 8\% of the Minimal Environmental ICF Core Sets. When compared with the Work Ability Index (WAI) and the World Health Organization Disability Assessment Schedule (WHODAS 2.0), the direct equivalences of the ICF codes were 36 and 44\%, respectively.

Conclusion: The Abilitator sufficiently comprehensively covers the relevant aspects to enable the assessment of the overall work ability and functioning of the population in a weak labour market position.

Keywords: Work ability, Functioning, Health, Well-being, Self-report, Unemployment, Employability, Inclusion, ICF, Content validity

\footnotetext{
* Correspondence: miia.wikstrom@ttl.fi

${ }^{1}$ Finnish Institute of Occupational Health, Helsinki, Finland

Full list of author information is available at the end of the article
} 


\section{Background}

It is well established that unemployment is associated with a lower educational level and poorer health and well-being [1-6]. In 2017 in the European Union (EU), the unemployment rate was $7.6 \%$ and of those who were unemployed, $45.1 \%$ were long-term unemployed [7]. Prolonged unemployment may lead to social exclusion, marginalisation, and inequality in working life [4, 8-10]. The evidence suggests that reducing unemployment would lead to improved quality of life and health outcomes and should be a priority [11].

Work ability can be defined as a combination of health, functioning, basic standard competence and the relevant occupational virtues required for managing reasonable work tasks in an acceptable environment $[12,13]$. It is associated with all factors of working life: the individual, the workplace, the immediate social environment, and the society [13]. It can be used to specify the expectations of employees in terms of the competence needed for different kinds of work, in disease prevention and health promotion and as an instrument to determine the degree and type of rehabilitation needed by individuals. It is also a central legal concept regulating sickness and social insurance policies [12].

Functioning is closely related to health and comprises a psychological, social, physical and cognitive dimension $[14,15]$. Psychological functioning is the ability to feel, experience, form perceptions of oneself and the surrounding world, plan life, find solutions, and make decisions [16]. Social functioning is manifested through one's role as an actor with and among others, interaction with social networks, social activities and participation, as well as experiences of coexistence and inclusion [17]. Inclusion means that a person feels they are a significant part of an entity with others. Inclusion is a process that can be observed through material, spiritual, social, and physical dimensions and can be viewed from a variety of perspectives, such as education or work [18]. Physical functioning includes the ability to physically perform everyday basic activities and meaningful leisure activities, as well as to work and study [19]. Cognitive functioning is the mental function related to the reception, processing, preservation, and use of knowledge [20].

The unemployed have lower work ability than those who are employed [21-24]. Contemporary working life places new and rapidly increasing demands on individuals' work ability, functioning and employability [25]. These pressures accumulate, especially among those who are in a weaker labour market position to begin with. This is a heterogenous group of people who repeatedly or continuously have difficulties gaining employment: for example, those with less education and fewer skills, disabilities, or chronic health problems, those experiencing long-term unemployment and those with migrant backgrounds [26-29]. These people may particularly benefit from individually targeted actions to improve their opportunities for participation and employment [30, 31].

The relationship between unemployment and health has shown to be bi-directional: poor health can cause unemployment and unemployment can cause poor health $[3,4]$. In addition to lower work ability, the unemployed have lower self-rated health and life satisfaction than those who are employed [1, 24, 32]. It has been estimated that in long-term unemployment, financial difficulties and a low educational level explain half of the factors related to low self-rated work ability [24]. Mental disorders, neurological disabilities, musculoskeletal problems and substance abuse challenges have also been associated with low work ability [27]. In addition, the long-term unemployed often have several simultaneous health impairments, which makes the individuality and multidimensionality of the assessment of their work ability and functioning even more difficult [26, 27].

Most Western European welfare states have a vast array of public, private or third sector services available to support and promote the health, rehabilitation, social well-being, education and employment of the workingage population. These services often need to assess work ability and functioning individually. It has been suggested that the resources of, for example, health services should focus more on those whose perceived health and work ability has started to decline [22, 33]. It has also been recognised that many work ability limitations go unnoticed by these services, resulting in unused opportunities for rehabilitation [2, 34, 35]. In terms of work ability, the unemployed can be split into three groups: 1) those with good work ability, 2) those unable to work, and 3) those whose work ability can be restored with adequate rehabilitation [27]. These groups vary greatly in their needs for support [34]. To direct resources appropriately, new approaches are needed to assess work ability and functioning more individually.

The challenges to assess work ability and functioning of those in a weak labour market position can be viewed from four operational angles. First, the individuals may not recognise the challenges in their work ability and functioning; they may find it difficult to express their own views of their life situation, perceived abilities and challenges. Factors such as long-term unemployment can lead to reduced self-esteem and feelings of shame [36], less trust in services, and a lower perceived ability to cope with working life [37]. We may need neutral, positively structured self-report instruments of work ability and functioning.

Second, a few generic, feasible and validated selfreport instruments exist for the multidimensional assessment of work ability and functioning among the 
unemployed [38, 39]. Current instruments are designed for professionals in vocational rehabilitation or occupational health services; instruments are needed that are easy to interpret without medical or other specific professional training, as the occupational backgrounds of the personnel in these services can vary.

Third, these services' use of assessment-based procedures and unified ways of encountering the unemployed individually are in their infancy [26]. Such processes are required for co-operation with service clients to create more focused service plans. These assessment procedures should simultaneously support the individual's agency.

Fourth, organisations providing employment and other welfare services should assess the effectiveness of their services [40]. Reliable information on clients' needs and the changes that take place during the service process is needed for planning the allocation of resources. PatientReported Outcome Measures (PROMs) have been suggested as a good measure of services' impact on clients' well-being and their ability to play an active role in society. PROMs are questionnaires for clients of different services on their health, functioning and health-related quality of life. The information collected from these subjective reports enable following the clients' progress and facilitating communication between professionals and clients and help improve the quality of services [41].

To meet these needs, we developed the Abilitator - a generic, multidimensional instrument for self-reporting of work ability and functioning among the population in a weak labour market position. It is a digital questionnaire that analyses responses and produces individual written feedback with suggestions for further actions to maintain or improve work ability and functioning. The main purpose of the Abilitator is to help individuals (clients) identify their strengths and challenges in terms of their work ability and functioning, thus improving their awareness of their life situation when accessing different services. The self-report aims to provide the client a structured basis for individual goal setting in a subsequent dialogue with professionals in health, rehabilitation, social services, education and employment services. Its purpose is to help the professionals work together with the clients to implement the most suitable measures and interventions to reach the set goals.

The aim of this study is to describe the development and assess the content validity of the Abilitator and its alignment with the International Classification of Functioning, Disability and Health (ICF) to assess the overall work ability and functioning of the population in a weak labour market position.

\section{Methods}

The Abilitator was developed at the Finnish Institute of Occupational Health (FIOH) by the Social Inclusion and the Change of One's Work Ability and Capacity (Solmu) project, which is a national co-ordination project funded by the European Social Fund (ESF) Priority 5 programme (2014-2020). The goal of this 'Social inclusion and combating poverty' ESF programme is to improve the work ability and functioning of people outside working life. The aim of Solmu was to co-develop feasible procedures and a method for evaluating changes and improvements in the participants' work ability and functioning during the projects funded by the ESF Priority 5 programme.

\section{Sample}

The clients participating in services provided by the ESF Priority 5 projects represented the target group sample. They were mainly of working age, had been unemployed for several years, and faced various problems related to their health, lifestyles and life situations. They participated in the projects voluntarily to improve their work ability, functioning and employment opportunities. On average they were 40 years of age, had been unemployed from 3 to 7 years and had little post-compulsory education.

The essential development of the Abilitator was carried out by an internal group of experts $(n=8)$ from FIOH representing medical, health, sport, behavioural, and social sciences. One member of this group was from THL. The first external expert panel included academic specialists $(n=30)$ from the fields of work ability, functioning and social inclusion. The second external expert panel included both professionals and target group clients, bringing expertise through experience to the development. The professionals $(n=700)$ had varying lengths of work experience with the target population, and their occupational backgrounds ranged from university research scientists to social workers and sports coaches. They mostly worked in ESF Priority 5 projects. The target group experts $(n=28)$ were clients who received the services in the ESF Priority 5 projects.

\section{Development}

The development of the Abilitator progressed through seven phases between 2014 and 2017 (Fig. 1). In Phase 1 , we reviewed the related theoretical models and the existing PROMs of work ability and functioning used in Finland and more widely in the EU. We searched Google Scholar and PubMed using terms such as work ability, functioning, functional capacity, model, method, concept, theoretical, self-report, self-assessment, and questionnaire. We also identified self-report instruments from the Finnish TOIMIA network's database, which contains guidelines for the measurement of functioning and evaluations of these measures [42]. The inclusion criteria for the instruments were their proven reliability, validity and wide use in previous research of the 


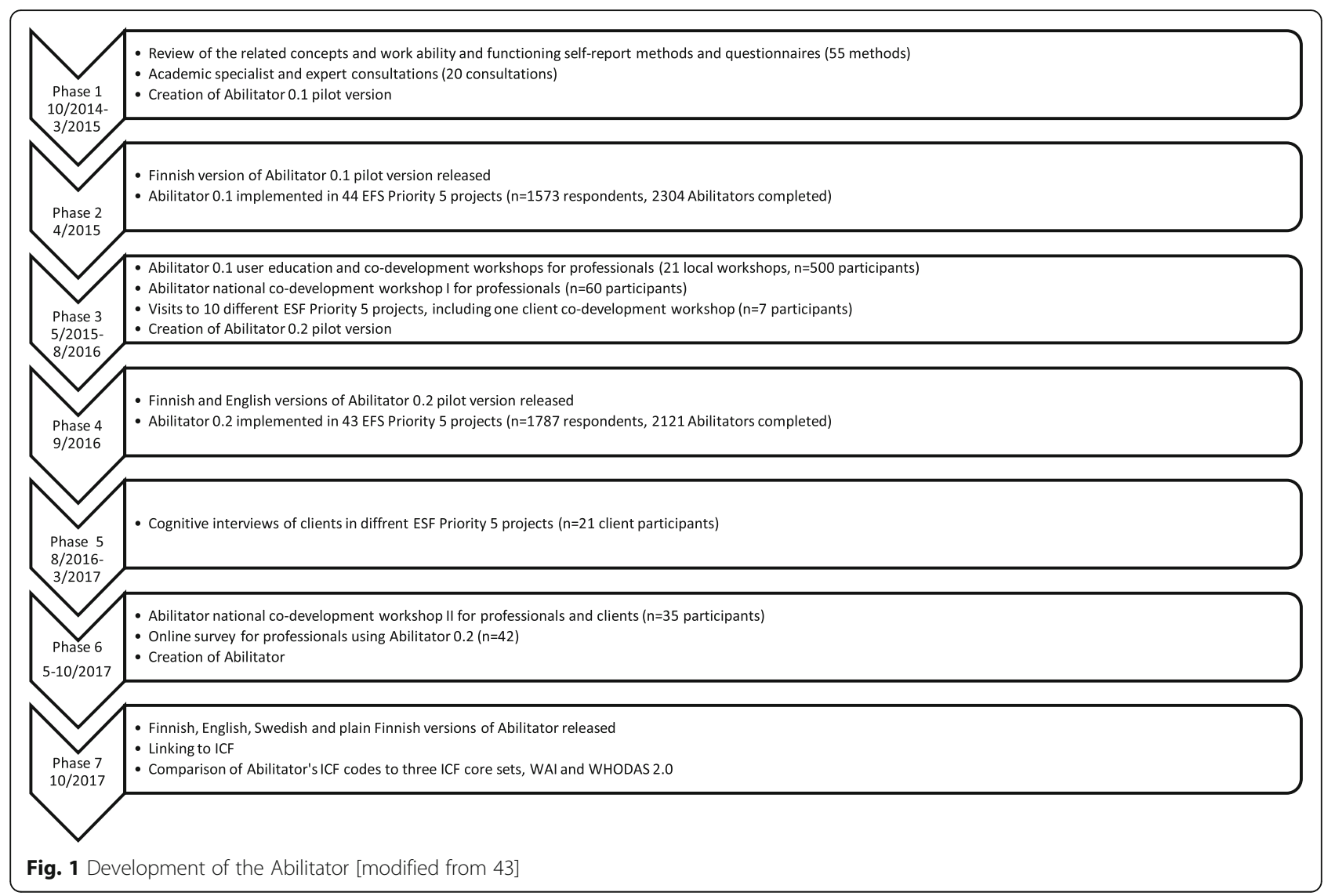

working-age population. Further inclusion criteria were free access, availability in the Finnish language and different occupational groups being able to use the instrument safely. The first version (0.1) of the Abilitator was formed based on the review and co-development with academic experts $(n=20)$.

After Abilitator 0.1 was implemented in 44 ESF Priority 5 projects in Phase 2, we co-developed it with professionals, academic experts and clients to form the second version (0.2) (Phase 3). The professionals' $(n=600)$ experiences of and suggestions regarding the content of Abilitator 0.1 were collected in 22 local or national co-development workshops. Each workshop covered the content of the whole questionnaire in a similar manner to determine: 1) whether each question was relevant for the target group, 2) whether each question was formulated in a way that was appropriate for the target group, and 3) what kind of alterations should be made to each question for them to better suit the target groups' needs or situations. Similar feedback was gathered from the professionals during 10 visits to different EFS Priority 5 projects. One group of clients $(n=7)$ also suggested question alterations and academic experts $(n=15)$ gave their input in separate encounters at this stage.
In Phase 4, Abilitator 0.2 was implemented in the ESF Priority 5 projects. After this, cognitive interviews were conducted with clients $(n=21)$ participating in five different national or local ESF Priority 5 projects (Phase 5) [43]. The interviewed groups had good geographical, gender and target group coverage. The aim of the interviews was to obtain information on how the respondents had processed and interpreted the questions of Abilitator 0.2. The interviews used a four-step question-answer process [44] related to the format, feasibility and comprehension of the questions. All the interviews were conducted by two interviewers and progressed following the same pattern. Each interview was recorded and transcribed.

In Phase 6, we sent an online survey to all the professionals $(n=144)$ using Abilitator 0.2 to collect additional feedback on the content, feasibility and format of the instrument. We also ran a second national co-development workshop with the professionals $(n=35)$. We used the information and feedback gained from the survey $(n=42)$, the workshop and the cognitive interviews to steer the development of Abilitator 0.2's content and layout. The feedback was again systematically gathered in written format and reviewed by the internal group of experts. The suggestions were grouped into similar feedback units and 
the decisions regarding changes to the questionnaire were made in the internal expert group's consensus meetings. At the end of Phase 6, the third version, i.e. Abilitator was ready. During each phase of the development, the professionals were given training and support materials on how to use the Abilitator with their clients and how to interpret the results.

When the content development was complete, the Abilitator was linked to the ICF (Phase 7). The main purpose of this was to translate the instrument's content into the internationally unified and consistent language of human functioning, which can be used as a reference for comparing health information. This linking was conducted in co-operation with the national ICF concept working group and followed the updated linking rules [45]. It was first conducted by two research scientists separately and consensus was reached in two separate sessions with three other ICF experts. The second purpose was to position the Abilitator among the ICFlinked self-report instruments measuring work ability and functioning, and to compare the Abilitator's ICF codes with the three ICF Core Sets most relevant to the target population; the generic set (7 codes), the brief vocational rehabilitation set (13 codes) and the minimal environmental set (12 codes) [46].

The Abilitator's ICF codes were further compared with two validated, central self-report instruments: the Work Ability Index (WAI) (14 codes) and the World Health Organisation Disability Assessment Schedule (WHODAS 2.0) (27 codes). The WAI is used in occupational health services and research to assess employee work ability in health examinations and workplace surveys [39]. It is developed by FIOH to help define the necessary actions for maintaining and promoting work ability. WHODAS 2.0 is a generic assessment instrument that provides a standardised method for measuring health and disability across cultures. It was developed from a comprehensive set of ICF items that are sufficiently reliable for measuring activities and participation [47].

\section{Content validation}

The content validation process of the Abilitator followed the guidelines of COSMIN [48, 49]. It was split into five phases: 1) definition of the construct to be measured and specification of the situation in which the instrument is used, 2) expert panels' assessment of the instrument's content during the development process, 3) consideration and provision of information on the instrument's content, 4) assessment of whether the instrument's content corresponded to the construct, and 5) assessment of whether the instrument's construct corresponded to the ICF framework of functioning and relevant ICF Core Sets and other instruments measuring the same construct. Phase 2 included the evaluation of face validity, which is the degree to which the measurement instrument seems to be an adequate reflection of the measured construct [49].

\section{Results}

Specification of measured construct and context of use

The literature review conducted in Phase 1 (Fig. 1) found eight different theoretical models for work ability [50] and two models for functioning. In the bio-medical model of work ability, an existing illness, impediment or disability determines a person's attributes and qualities as a worker $[13,51,52]$. In the balance model, work ability is the equilibrium between the individual and work-related factors $[51,53]$. The psychosocial model emphasises the psychological and psychosocial factors connected to work participation and return to work [54-57]. In the multidimensional models and the bio-psycho-social models, work ability is a holistic, comprehensive entity in which individual resources and work-related factors are combined by the operational environment and social support $[13,14,27,58]$. In the employability model, work ability combines all the individual and societal actions that help a person become employed, stay employed and advance their career $[59,60]$. According to the model emphasising the integration of the individual at the workplace, the concept of work ability is based on continuous change in work and work organisation [61, 62]. Work ability can also be considered a social construct that is constituted by and differs between different societies and systems [63].

As with the concept of work ability, biomedical and biopsychosocial models have been used to describe functioning and health [58]. An internationally accepted way of structuring the concept of functioning is ICF [15], the framework of which provides a standard language and multi-purpose classification of disability and health [64]. Functioning is a collective umbrella term of the ICF that describes a person's body structures and functions and their capacity to perform daily activities in the environment in which they live. The ICF is a biopsychosocial model that combines the biomedical, social and environmental aspects of human functioning, health and disability $[14,65]$. It can be used as an instrument to collect comparable data to support evidence-based decisionmaking in health and health-related sectors. WHO and the ICF Research Branch have created Core Sets of ICF which the essential relevant categories for specific health conditions and health care contexts [46].

The ICF framework reflects six different aspects of health and disability: health condition, body structure and body function, activity, participation, environmental factors, and personal factors [66]. Diseases or disorders, i.e. health conditions, are included in the conceptual model of health, but are classified in the International 
Classification of Diseases and Related Health Problems (ICD) [67]. Functioning should be understood as a continuum ranging from completely able (non-problematic) to completely disabled (problematic) and is the result of complex multifactorial interaction between the six components [68].

\section{Concepts of work ability and functioning in the Abilitator}

The Abilitator is based on the multidimensional model of work ability [13] as this model describes both individual resources and the operational environment. We chose the ICF biopsychosocial model [14] for functioning because it is widely accepted in situations of multiple and long-term impairments of health [55].

The selected multi-dimensional work ability model is called the House of Work Ability [13, 69]. It has four levels that depict the relationship between individual resources, work-related demands, and the social and operational environments that affect both individual resources and working life. The three lower levels of the model describe individual resources such as health and functioning, competence and work experience, values, attitudes, and motivation. The top level is the level of work and includes factors related to work, working conditions, work community and leadership. Individual work ability is created by the balance between all the levels of the house, which are also significantly affected by social networks, communities and environments outside the workplace $[13,70,71]$. The Abilitator does not cover the top level, because those in a weak labour market position are to a large extent without employment.

The ICF biopsychosocial model of functioning $[15,58]$ sees operational constraints as a mismatch between the health of a person and the requirements of their life situation. To minimise this disparity, the impact of environmental and individual factors must also be considered in addition to the person's health-related factors. These include available support and services, work situation, family, hobbies, motivation, and religion [72, 73].

The construct of the Abilitator can be further described using a framework of four central and partly overlapping concepts that can be linked to the population in a weak labour market position. These concepts are: 1) work ability $[12,13,69], 2)$ health and functioning [15], 3) inclusion [18] and 4) employability [27, 60]. They include a variety of factors, some of which are defined in the Abilitator and some not, as shown in Fig. 2.

\section{Specification of the Abilitator's context of use}

The Abilitator was developed to be suitable for individual and multidimensional self-assessment of the work ability and functioning of the population in a weak labour market position. The use contexts in the ESF projects included: to assess the service clients' situations individually, to set goals, to design the best service plans to reach the set goals, and to make changes in work ability and functioning apparent to both clients and professional. This information was further used to analyse the effect of the different actions on larger groups of service clients taking part in ESF Priority 5 projects.

\section{Utilisation of expert panels in co-development and assessment of content}

An example of the expert panels' influence on the Abilitator content are questions D8 and D9 [Additional file 1]. Abilitator 0.1 contained two items for screening depression in primary care [74]. During Phase 3, systematic negative feedback from the target group, the professionals and the academic experts led to the removal of these items. The questions were considered too diagnostic to be used by professionals, too invasive to be answered by the respondents, and too difficult to evaluate in the context of their use. However, issues such as taking the initiative in everyday activities were still considered important. Therefore, the group of experts formulated two completely new items, D8 and D9. These questions were added to Abilitator 0.2 [Additional file 1] and the practical group of experts assessed their feasibility during Phases 5 and 6 . Due to the systematically positive feedback received, Questions D8 and D9 of the Abilitator remained unchanged.

Abilitator 0.2 contained 76 questions and the online version also offered personal feedback. The content and format of this feedback was developed with the external expert panels along with the content of Abilitator 0.2. The internal expert group decided not to include all the questions in the feedback the Abilitator 0.2 gives the respondent because one single answer is not always enough to make meaningful assumptions about the respondent's situation. However, the interpretations of all the questions were analysed for the professionals in the Abilitator user manual.

Based on the literature review on instruments in Phase 1 the internal group of experts created the structure and content of Abilitator 0.1 from pre-existing questionnaires and some newly formed questions into one selfreport questionnaire. The literature review identified 55 self-report instruments of work ability and functioning, of which 14 were used based on face validity or partially by combining the most relevant questions. The consultations of academic specialists $(n=20)$ improved the 0.1 pilot version's content. It was also decided that the Abilitator would retain the questions on overall functioning and work ability i.e. Questions B3 and B4 [Additional file 2] throughout the development process. This was to ensure that ESF Priority 5 projects could assess the overall change in work ability and functioning of their clients even if other parts of the Abilitator changed during its development. 


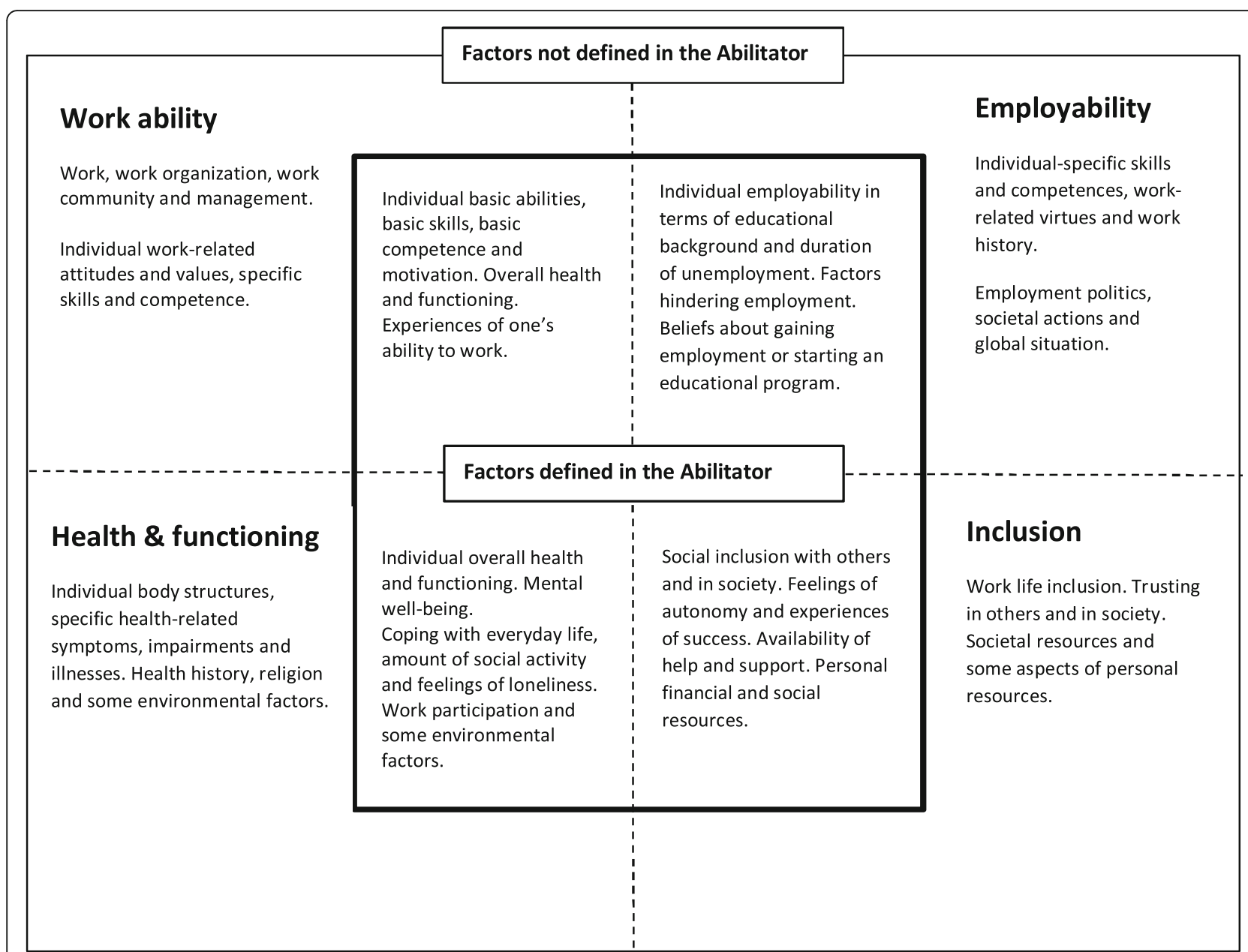

Fig. 2 Construct of the Abilitator, consisting of concepts of work ability, health and functioning, inclusion and employability. The inner square features the factors of each concept that are defined in the Abilitator and the outer square those that were excluded. The dotted lines reflect the overlapping of the four concepts

We chose the following topics as the main elements of Abilitator 0.1: 1) Work ability and perceived health, 2) Everyday skills, 3) Social functioning and social involvement, 4) Psychological functioning, 5) Cognitive functioning, 6) Physical functioning, and 7) Background information. These topics covered the first three levels of the House of Work Ability and its dimensions of family, close community and society. Abilitator 0.1 contained 57 questions, of which 30 (54\%) were taken directly from pre-existing questionnaires [Additional file 1]. The rest were newly-formed questions covering target groupspecific topics that had either not been evaluated by a selfassessment method before or for which the formulation of the pre-existing questions did not directly meet the Abilitator criteria; for example, positive question format, equality, generality, and comprehensiveness.

During the development process, the content of the Abilitator was modified twice [Additional file 1]. All the feedback on Abilitator 0.1 and 0.2 was systematically gathered in written format and reviewed in detail by the internal group of experts (Phase 3, 5 and 6, Fig. 1). The suggestions were grouped into similar feedback units and the decisions regarding changes to the questionnaire were made in the internal expert group's consensus meetings. As a result, 25\% of the questions in Abilitator 0.1 remained unchanged, 50\% were modified and 25\% were removed. The unchanged questions were perceived as feasible for and by the target group and for evaluative purposes. The content or formulation of the questions was changed if: 1) the questions were not perceived as equal, 2) the questions' original design was not perceived as suitable for the target group, 3) the questions' original design did not reveal the desired issue precisely enough, 4) the questions required more text to support their comprehension, 5) the questions' themes were perceived as too narrow or extensive, 6) the questions lacked important areas or response options and 7) the questions had too many or too few response options. The 
questions removed from Abilitator 0.1 were: 1 ) not answered as regularly as the others, 2) perceived as repetition, 3) not perceived as appropriate for or by the target population, 4) not perceived as covering the desired aspect, 5) not perceived as equal and 6) too difficult to answer. Nineteen completely new questions were added to Abilitator 0.2. If important issues or sub-issues were completely missing, or if new questions were needed to better suit the target groups' situation, the removed question was replaced by a new one.

In Abilitator 0.1, the recall period varied from the present to 2 weeks or a month. According to the feedback, this was confusing to both the respondents and the professionals. Therefore, in Abilitator 0.2, the recall period was harmonised to the current situation, except for Section D (Mind) in which the recall period was set as one month. In addition, the scales were harmonised and presented either horizontally or vertically, and the best option was always at the furthest right or at the top, respectively.

When the final Abilitator was created, $60 \%$ of the questions in Abilitator 0.2 remained unchanged, 38\% were modified and $2 \%$ were removed. The unchanged questions were perceived as feasible for and by the target group and for evaluation purposes. The content or formulation of the questions was changed if: 1) the questions required more text to support their comprehension, 2) the order of the questions was not logical within the sections of the questionnaire, 3) the question's topic was too extensive to answer and needed splitting into two separate questions. Based on the feedback received, we added three new questions to the questionnaire to obtain a broader view of the respondent's situation. At the end of the development process, the Abilitator contained 84 questions of which 17 were items from existing questionnaires, and 67 were either modifications or completely new items. The content of the personal feedback did not change significantly.

\section{Information on the Abilitator's content and its use in practice} The Abilitator contains nine sections: A. Personal information, B. Well-being, C. Inclusion, D. Mind, E. Everyday life, F. Skills, G. Body, H. Background information, and I. Work and the Future (Fig. 3). Each section contains 4-14 questions. In Fig. 3, the Abilitator's sections are further linked to general concepts and the Abilitator's concept framework presented in Fig. 2. The whole questionnaire is presented in Additional file 2 and can also be accessed online [75].

The interpretation of the results as given in a respondent's written feedback can be seen in Additional file 3 . The feedback is built directly on the response options and has no external benchmark figures. The measure of each section is a summary scale of the selected item. The points received are converted into percentages: the minimum score is $0 \%$ and the maximum $100 \%$. The feedback is grouped on the basis of the respondent's situation per sections B-G: 1) the situation is good, 2) the situation is fairly good, but has some possible challenges and 3) the situation is fairly poor or poor. If the respondent evaluates some items as very poor and others as good, the feedback indicates possible challenges. The

\begin{tabular}{|c|c|c|}
\hline Abilitator's sections & General concepts & Concept framework \\
\hline $\begin{array}{l}\text { A. Personal information } \\
\text { B. Well-being } \\
\text { C. Inclusion } \\
\text { D. Mind } \\
\text { E. Everyday life } \\
\text { F. Skills } \\
\text { G. Body } \\
\text { H. Background } \\
\text { I. Work and future }\end{array}$ & $\begin{array}{l}\text { Overall health and functioning } \\
\text { Social activity } \\
\text { Social activity with others and society } \\
\text { Feelings of autonomy and success } \\
\text { Availability of help and support } \\
\text { Loneliness } \\
\text { Mental well-being } \\
\text { Coping with everyday life } \\
\text { Basic skills } \\
\text { Basic abilities } \\
\text { Basic abilities } \\
\text { Basic competence } \\
\text { Education } \\
\text { Environmental factors } \\
\text { Social resources } \\
\text { Personal financial resources } \\
\text { Beliefs about gaining employment or starting education } \\
\text { Motivation } \\
\text { Work participation } \\
\text { Duration of unemployment } \\
\text { Factors hindering employment }\end{array}$ & $\begin{array}{l}\text { Health and functioning, Work ability } \\
\text { Health and functioning } \\
\text { Inclusion } \\
\text { Inclusion } \\
\text { Inclusion } \\
\text { Health and functioning } \\
\text { Health and functioning } \\
\text { Health and functioning } \\
\text { Work ability } \\
\text { Work ability } \\
\text { Work ability } \\
\text { Work ability } \\
\text { Employability } \\
\text { Health and functioning } \\
\text { Inclusion } \\
\text { Inclusion } \\
\text { Employability } \\
\text { Work ability } \\
\text { Health and functioning } \\
\text { Employability } \\
\text { Employability }\end{array}$ \\
\hline
\end{tabular}

Fig. 3 Sections of the Abilitator in relation to its general concepts and concept framework 
Abilitator's content and its development versions 0.1 and 0.2 , the scales, and the ICF codes by question are illustrated in Additional file 1. Another way in which to interpret the results is to do so question by question. The instructions for this are presented in the Abilitator's user manual, currently only available in Finnish [75].

In practice, the Abilitator can be used in different ways. A service actor working in, for example, employment services can send the client a personal link to the Abilitator via email well before a scheduled appointment. On average the questionnaire takes $15-20$ min to complete. The client can complete the questionnaire online independently or with a close person. Another option is that the service actor interviews the client and enters the responses directly into the online version of the Abilitator. A third option is that the service actor either gives or sends the Abilitator questionnaire in paper format to the client. The client then completes the questionnaire and returns it to the service actor, who enters the information into the online version.

The advantage of the online version of the Abilitator is that both the client and the service actor can see the results and personal feedback and prepare for their appointment accordingly. During the appointment, the client and the service actor can discuss the results, and plan targets and actions to improve or sustain the client's work ability or functioning if necessary. In an ideal situation, they arrange a follow-up appointment during which they evaluate whether these targets have been met.

\section{Correspondence between the Abilitator's content and its construct}

The Abilitator covered 79 ICF codes, of which 14 (18\%) described body functions and structures (b), 40 (50\%) activities and participation (d), 10 (13\%) environmental factors (e) and 15 (19\%) personal factors (pf). The ICF codes describing body structures and functions were related to global and specific mental and respiratory system functions. The codes related to activities and participation covered learning and applying knowledge, carrying out general tasks and demands, communication, mobility, self-care, domestic life, interpersonal interactions and relationships, and major life areas. The codes covering environmental factors described products and technology, support, relationships, and attitudes. The correspondence of all the Abilitator's items to the ICF categories is illustrated in Fig. 4 and Additional file 1.

\section{Assessment framework for the correspondence between the Abilitator and its construct}

The direct equivalence of the Abilitator to the generic set was $4 / 7$ codes (57\%); to the brief vocational rehabilitation set, $10 / 13$ codes (77\%); and to the minimal environmental set, $1 / 12$ codes $(8 \%)$. In addition, two d4-category codes of the generic set, one e4-category code of the brief vocational rehabilitation set, and the e3-category codes of the minimal environmental set were indirectly represented in the Abilitator at another category level [Additional file 4].

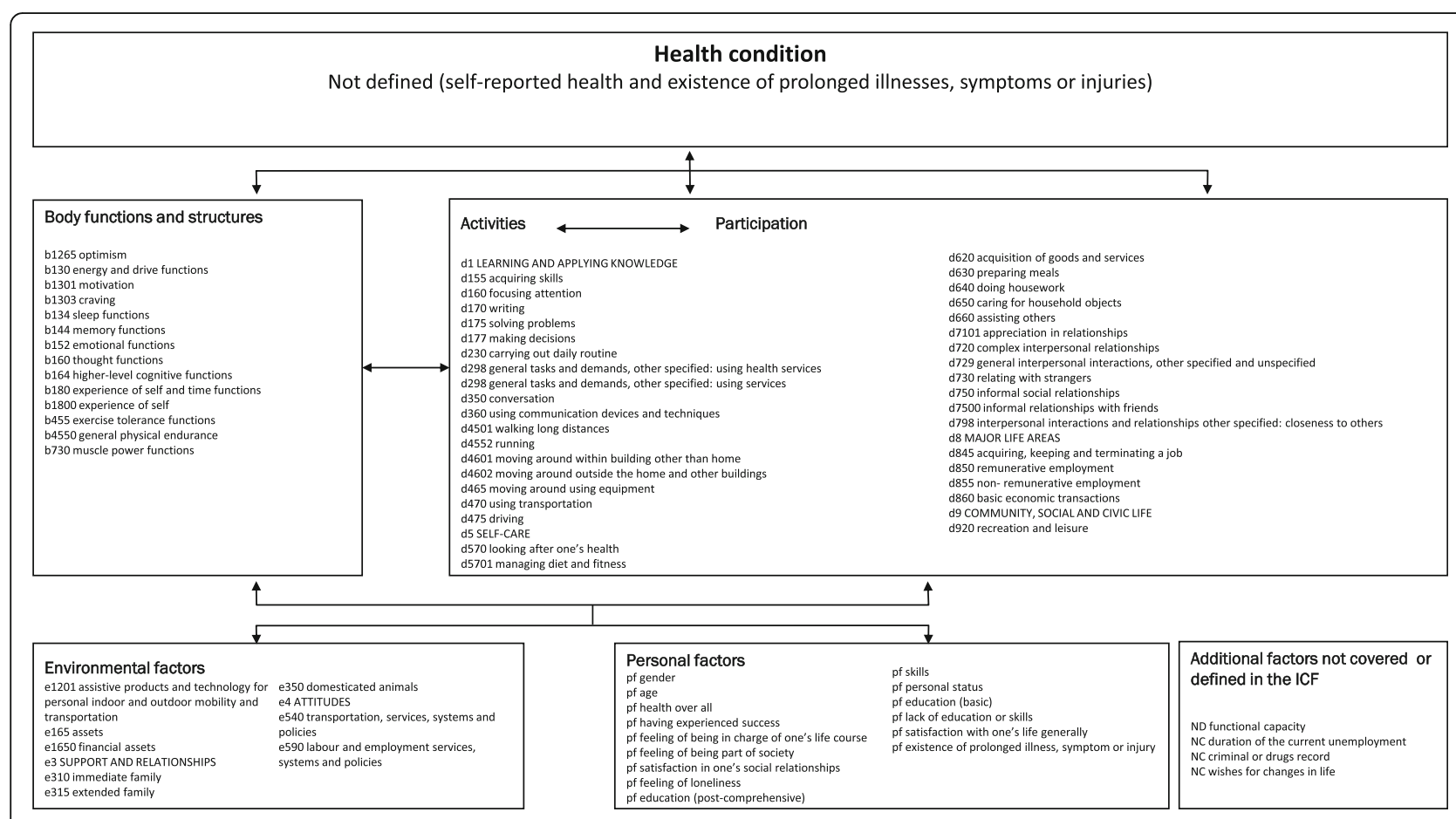

Fig. 4 Content of the Abilitator described using the ICF framework 
The direct equivalence of the Abilitator was 5/14 (36\%) WAI codes. In addition, similar aspects of four codes were indirectly covered in the e3- and e4categories. The direct equivalence of the Abilitator was 12/27 (44\%) codes of WHODAS 2.0, and there were only minor differences in the codes concerning categories $\mathrm{d} 4$ and $\mathrm{d} 5$ [Additional file 4].

\section{Discussion}

The purpose of this study was to assess whether the Abilitator covers the relevant aspects needed to assess the overall work ability and functioning of the population in a weak labour market position. The study shows that the Abilitator covers the relevant aspects sufficiently comprehensively to enable this assessment. In terms of the content coverage, the Abilitator covers the basic individual-related elements of work ability, health, functioning, employability, and inclusion. In terms of the content relevance, the sections in the Abilitator: 1) apply to general concepts of work ability and functioning, 2) are relevant to the target population, and 3) are relevant to the purpose of the application of the instrument as a means of evaluation.

As a part of the five-phase content validation process [36, 48], we first specified the construct to be measured and then described the context of the instrument's use. We used the multidimensional work ability theory $[13,69]$ and the biopsychosocial model of functioning $[15,58]$ as a basis for the Abilitator. Work ability and functioning are usually defined in relation to work and health. However, as an unemployed person has no work, the contents related to work ability and functioning in the Abilitator correspond to the general demands of working life (Fig. 2). In addition, when developing the construct, we reviewed the work ability and functioning of the target population as well as the context in which the Abilitator was to be implemented in different services.

Second, we used various expert panels. During the development process, an internal group of experts and several external groups of academic experts, professionals and clients evaluated the contents' relevance and coverage as well as the questionnaire format. In addition, cognitive interviews were conducted in the target population to improve the relevance and comprehensiveness of the Abilitator. The feedback from the expert panels during the development of the instrument considerably altered the Abilitator's content, as $80 \%$ of the items in the pilot versions were modified.

The expert panels' role was also important after the Abilitator's usability and accessibility had been improved. On one hand, the digital format made the Abilitator quick and easy to administer at any phase of the service process. On the other hand, the option of completing the Abilitator on paper was crucial for some service clients. The questions were phrased positively and simply to help the service clients self-report their situation in a neutral way. Multidimensionality and individuality were considered so that both the respondents and the professionals could receive enough information to advance in the most suitable service process. At the same time, the length of the questionnaire was restricted to prevent it becoming too long and heavy for the respondents to answer and the professionals to analyse. The interpretation of the results was made easy for the service clients through short, positively phrased written feedback. For the professionals, the resulting interpretation was made as uncomplicated as possible through educational material and user support.

Third, we considered the information regarding the content of the measurement instrument [36, 48]. The theoretical framework of the Abilitator was described and full details of the self-report questionnaire was provided [Additional file 2] with the interpretation of the results [Additional file 3]. The development of the Abilitator was also described in detail (Fig. 1).

Fourth, to clarify whether the Abilitator corresponded to the construct, we linked it to the ICF (Fig. 4). This revealed that the Abilitator covered 79 ICF codes, which were distributed to five different aspects of health and disability described by the ICF. The health condition aspect was not defined, as the Abilitator does not cover specific health-related disorders or diseases (ICD). Information on self-rated health (Question B2) and the existence of any long-term illness (Question G8) were considered significant for safe interpretation and personal data protection purposes.

Fifth, the Abilitator's ICF codes were further compared with the three ICF Core Sets most relevant to the target population [Additional file 4]. The areas of functioning missing from the Abilitator were sensation of pain, stress management, and the existence of health services, systems, and policies. Furthermore, the products and technologies described in the ICF minimal environmental Core Set were not fully covered in the Abilitator. However, overall, the Abilitator seemed to adequately cover functioning when compared with the selected ICF Core Sets. If at some point the Abilitator is revised, it might be appropriate to consider whether these missing items should be added to the questionnaire.

There are no gold standard measures of self-assessed work ability and functioning. Therefore, using the ICF framework, we compared the content of the Abilitator with that of two validated, commonly used self-report instruments i.e. the WAI and WHODAS 2.0. The direct ICF correspondence between both instruments and the Abilitator was quite low. This might be because the WAI is directed more toward assessing the work ability 
and diagnosed ill-health of those who are in employment [76], and the Abilitator focuses more on the aspects of work ability related to the unemployed i.e. individual resources such as self-rated health and functioning, employability, inclusion, and motivation. Although both the Abilitator and the WHODAS 2.0 cover many of the same ICF categories in terms of activities and participation, their contents differ. The WHODAS 2.0 assesses participation in terms of ICF domain activities and participation, whereas the Abilitator also assesses personal and environmental factors.

The Abilitator's content validation process was based on the framework [48] recommended by the COSMIN panel [49]. Its content validation and development processes are similar to those described in the PROMIS ${ }^{\circ}$ Instrument Maturity Model [77], which lists the stages of instrument scientific development from conceptualisation through evidence of psychometric properties in multiple diverse populations. According to this model, the Abilitator is now at stage 1: conceptualisation and item pool development are complete. However, some differences to the PROMIS ${ }^{\bullet}$ model must be noted. The Abilitator's development process contained extensive codevelopment with professionals, reflecting their views of the work ability, functioning and life situation of the target population. The different sections of the Abilitator represent areas of life which may each contain several latent traits, and the measure of each section is a summary scale of these items. The items in the different sections of the Abilitator are based more on theory and usefulness in practice than on a data-driven approach, where items are selected to reflect a single well-defined latent trait. Therefore, each section of the Abilitator is to be interpreted as a sensible, meaningful combination of items of wide conceptual categories, derived from input of professionals during the development process.

\section{Strengths and limitations of the study}

The first strength of this study is that its structured, long-term, multidimensional development process was combined with extensive co-development. The use different of expert panels led to combining science and practice, which improved the Abilitator's content, usability and accessibility. The second strength is its clear, well-structured content validation process and its documentation. The third strength relates to the extensive process of linking the Abilitator to ICF, in which the cooperation and work contribution of academic experts was crucial.

The limitations of this study relate to both the Abilitator as a self-report method and the study itself. The first Abilitator-related limitation concerns the interpretation of results. As the assessment is within-subject only and the scales within it are not yet validated as such, the
Abilitator cannot yet be used to measure the level of work ability and functioning. On one hand, no benchmark data on the Abilitator are available because the instrument has only been used in the population in a weak labour market position. On the other hand, very strong benchmark data are available for some parts, because the Abilitator contains the same items as the nationally representative population's health, functioning and welfare surveys [78, 79], including self-rated health and work ability. However, at this point, the Abilitator results may be presented as an approximation of work ability and functioning. The Abilitator should only be used as an indicative instrument, to indicate the respondent's work ability- and functioning-related resources when the interpretation of the results is the same as the content of the questions.

The second limitation related to the Abilitator is its lack of coverage on work ability factors especially those of work-related specific skills, competence, values and attitudes. If the Abilitator is revised, it might be appropriate to consider whether these missing factors should be added to the questionnaire.

The third Abilitator-related limitation relates to the context of its use. First, the situation in which the Abilitator is applied needs to be considered, that is, 1) in what services the assessment is conducted, 2) how it is applied, 3) what information can be utilised in the context of use, and 4) what kind of actions can be carried out in the services in terms of the results. Furthermore, the process of applying the Abilitator needs to be evaluated, i.e. how well the method sits in the processes carried out in the services, how the method is implemented, and how is it realised. These aspects need to be investigated in future studies.

The first methodological limitation concerns the lack of a systematic review of existing self-report instruments on work ability and functioning. The literature review mainly focused on methods available in Finnish and with free access. Therefore, we may have missed some potential methods during the Abilitator's initial development.

The second limitation relates to the groups participating in the co-development of the Abilitator, as they were mostly professionals and clients in the ESF Priority 5 projects. This may have led to the exclusion of some relevant views of other professionals working with or belonging to the target population.

We may also have missed some important opinions of professionals and the target group in the co-development workshops. Moreover, only 28 service clients gave direct feedback on the Abilitator's content. Even though the professionals delivered the views of the service clients to the internal group of experts during the co-development process, their number was low in proportion to the number of professionals $(n=700)$. Therefore, future research 
on the Abilitator should specifically focus on service clients' feedback.

Despite these limitations, the Abilitator has the potential to become a generic, feasible, multidimensional self-report instrument for evaluating the work ability and functioning of individuals in a weak labour market position who use different services. The information on work ability and functioning derived from the Abilitator could be used in these services to discuss and work together with individuals towards the most effective service plans. The positive and empowering form of the Abilitator could also support individuals' agency. For organisations providing these different services, the Abilitator could be an instrument for systematic data collection on work ability and functioning. It has been suggested that different actors producing health and employment services should form closer partnerships and co-operative networks [33]. The most beneficial situation would be one in which the service clients, actors and organisations operate within the same system when assessing work ability and functioning. The Abilitator could be the unified instrument used in different services to strengthen this co-operation when working with the population in a weak labour market position.

\section{Conclusion}

The purpose of this study was to describe the development and assess the content validity of the Abilitator in terms of content relevance and coverage. From a professional perspective, the Abilitator covers the relevant aspects sufficiently comprehensively to be able to assess the overall situation of work ability and functioning of the population in a weak labour market position. Future studies on the Abilitator's reliability, structural validity, concurrent and predictive validity, and ability to detect changes over time are needed to gain a more comprehensive view of its applicability.

\section{Supplementary information}

Supplementary information accompanies this paper at https://doi.org/10. 1186/s12889-020-8391-8.

Additional file 1. The development of the content of the Abilitator, description of the main concept and ICF category for each question [39, 74, 78-88].

Additional file 2. The Abilitator questionnaire.

Additional file 3. The interpretation of the Abilitator's results as it is given in a respondent's written feedback.

Additional file 4. The comparison of ICF codes of the Abilitator, ICF Generic Core Set, ICF Vocational Rehabilitation Core Set, ICF Environmental Factors Core Set, The Work Ability Index (WAI) and WHO Disability Assessment Schedule (WHODAS 2.0). The ICF category of personal factors (pf) is not included.

\section{Abbreviations}

COSMIN: COnsensus-based Standards for the selection of health Measurement INstruments; ESF: European Social Fund; EU: European Union; FIOH: Finnish Institute of Occupational Health; ICD: International Classification of Diseases and Related Health Problems; ICF: International Classification of Functioning, Disability and Health; pf: ICF category of Personal Factors; PROMIS: Patient-Reported Outcomes Measurement Information System; PROMs: Patient-Reported Outcome Measures; SOLMU: Social Inclusion and the Change of One's Work Ability and Capacity-project; THL: Finnish Institute for Health and Welfare; WAI: Work Ability Index; WHO: World Health Organization; WHODAS: WHO Disability Assessment Schedule

\section{Acknowledgements}

We acknowledge the academic experts who commented on the Abilitator's structure and content during the different phases of the questionnaire's development. We greatly acknowledge the professionals and the clients of the local Finnish ESF Priority 5 projects who commented on the Abilitator's content and took part in the questionnaire's co-development and cognitive interviews. We also acknowledge the Finnish National TOIMIA network for contributing to the process of linking the Abilitator to the ICF.

\section{Authors' contributions}

MW was responsible for the study design, data gathering, data analyses, and writing of the manuscript. MW also coordinated the process of the Abilitator's development. HA, MS, AK and MJ contributed to the data analyses and critically revised the manuscript. HA played a central role in the process of linking the Abilitator to the ICF and in coordinating the co-operation with the TOIMIA network in the linking process. MS participated in data gathering, user education, co-development workshops, and the cognitive interviews. MJ is the principal investigator of the Abilitator research. All the authors have read and approved the manuscript.

\section{Funding}

The funding for this study was provided the European Social Fund (ESF) Priority 5 programme. The funders played no role in the study design, data collection, data analysis, interpretation or writing of the report.

\section{Availability of data and materials}

The raw material for this study not found in the text or the additional files contains qualitative notes from the co-development process. Access to this material can be requested from the corresponding author Miia Wikström, miia.wikstrom@ttl.fi. The raw material from the cognitive interviews can be accessed by contacting Kirsi Unkila, kirsi.unkila@ttl.fi. The ICF codes for WHODAS 2.0 and WAI are openly available on www.terveysporttifi/dtk/tmi/koti and for the Generic, Vocational Rehabilitation (brief) and Environmental Factors (minimal set) ICF Core Sets on www.icf-core-sets.org, respectively.

\section{Ethics approval and consent to participate}

All parts of this study were approved by the ethics board of the Finnish Institute of Occupational Health in June 2017. The three external expert panels involved in the co-development process were informed both verbally and in writing about the research and voluntary participation was emphasized before the co-development took place. In addition, the members of the practical expert panels of professionals and target group clients signed an informed consent to participate in the co-development work shops or cognitive interviews. The academic expert panels gave a verbal consent to voluntarily participate as a specialist to improve or co-develop the Abilitator's content.

\section{Consent for publication}

Not applicable.

\section{Competing interests}

The authors declare that they have no competing interests.

\section{Author details}

${ }^{1}$ Finnish Institute of Occupational Health, Helsinki, Finland. ${ }^{2}$ Finnish Institute for Health and Welfare, Helsinki, Finland. ${ }^{3}$ Finnish Institute of Occupational Health, Tampere, Finland. ${ }^{4}$ Faculty of Social Sciences, University of Helsinki, Helsinki, Finland. ${ }^{5}$ Research Institute of Psychology, SWPSSWPS University of Social Sciences and Humanities, Wroclaw, Poland. 'UKCRC Centre of Excellence for Public Health (Northern Ireland), Queen's University Belfast, Belfast, UK. 
Received: 6 August 2019 Accepted: 24 February 2020

Published online: 14 March 2020

\section{References}

1. Griep Y, Kinnunen U, Nätti J, De Cuyper N, Mauno S, Mäkikangas A, De Witte $H$. The effects of unemployment and perceived job insecurity: a comparison of their association with psychological and somatic complaints, self-rated health and life satisfaction. Int Arch Occup Environ Health. 2016; 89:147-62.

2. Tefft N, Kageleiry A. State-Level Unemployment and the Utilization of Preventive Medical Services. Health Serv Res. 2014;49(1):186-204.

3. Janlert $U$, Winefield A, Hammarström A. Length of unemployment and health-related outcomes: a life-course analysis. Eur J Public Health. 2015: 25(4):662-7.

4. Schuring M, Robroek S, Otten F, Arts C, Burdorf A. The effect of ill health and socioeconomic status on labor force exit and re-employment: a prospective study with ten years follow-up in the Netherlands. Scand J Work Environ Health. 2013;39(2):134-43.

5. Schmitz $\mathrm{H}$. Why are the unemployed in worse health? The causal effect of unemployment on health. Labour Econ. 2011;18:71-8.

6. Mastekaasa A. Unemployment and Health: Selection Effects. J Community Soc Psychol. 1996;6:189-205.

7. Organisation for Economic Co-operation and Development (OECD). Labour Force Statistics 2017. http://www.oecd.org/ . Accessed 2 Feb 2019.

8. Oksanen K. Valtioneuvoston tulevaisuusselonteon 1. osa. Jaettu ymmärrys työn murroksesta. Government Report on the Future, part 1. [A shared understanding of the transformation of work]. Helsinki: Prime Minister's Office; 2017. Finnish. Available from: http://urn.fi/URN:ISBN:978-952-287-432-0.

9. Tøge A, Blekesaune M. Unemployment transitions and self-rated health in Europe: A longitudinal analysis of EU-SILC from 2008 to 2011. Soc Sci Med. 2015;143:171-8

10. Robroek S, Schuring M, Crozen S, Stattin M, Burdorf A. Poor health, unhealthy behaviors, and unfavorable work characteristics influence pathways of exit from paid employment among older workers in Europe: a four-year follow-up study. Scand J Work Environ Health. 2013;39(2):125-33.

11. Paul K, Moser K. Unemployment impairs mental health: Meta-analyses. J Vocational Behav. 2009:74:264-82.

12. Tengland P-A. The concept of work ability. J Occup Health. 2011;21:275-85.

13. IImarinen J, Gould R, Järvikoski A, Järvisalo J. Diversity of Work Ability. In: Gould R, Ilmarinen J, Järvisalo J, Koskinen S, editors. Dimensions of Work Ability. Results of the Health 2000 Survey. Helsinki: Finnish Centre for Pensions, The Social Insurance Institution, National Public Health Institute, Finnish Institute of Occupational Health; 2008. p. 13-23.

14. World Health Organization (WHO). How to use the ICF. A Practical Manual for using the International Classification of Functioning, Disability and Health (ICF). Geneva: WHO; 2013.

15. World Health Organization (WHO). International classification of functioning, disability and health: ICF. Geneva: WHO; 2001.

16. Aalto A-M. Suositus psyykkisen toimintakyvyn mittaamiseksi väestötutkimuksissa [Recommendation for measuring psychological functioning in population research]. The Finnish TOIMIA network. 2011. www.thl.fi/toimia. Accessed 11 Nov 2018.

17. Tiikkainen P. \& Heikkinen R-L. Sosiaalisen toimintakyvyn arviointi ja mittaaminen väestötutkimuksissa [The evaluation and measurement of social functioning in public health studies]. The Finnish TOIMIA network. 2011. www.thl.fi/toimia. Accessed 11 Nov 2018.

18. Leemann L, Kuusio H, Hämäläinen R-M. Sosiaalinen osallisuus [Social Inclusion]. Sosiaalisen osallisuuden edistämisen koordinaatiohanke (Sokra). Helsinki: Finnish Institute for Health and Welfare; 2015. Finnish. Available from: www.thl.fi/sokra.

19. Painter P, Steward AL, Carey S. Physical Functioning: Definitions, Measurement, and Expectations. Adv Ren Replace Ther. 1999;6(2):110-23.

20. Tuulio-Henriksson A. Kognitiivisen toimintakyvyn arviointi väestötutkimuksissa [The evaluation of cognitive functioning in public health studies]. The Finnish TOIMIA network. 2011. www.thl.fi/toimia. Accessed 11 Nov 2018

21. Hult M, Pietilä A-M, Koponen P, Saaranen T. Good work ability among unemployed individual: Association of sociodemographic, work-related and well-being factors. Scand J Public Health. 2017;7:1-7.

22. Hult M, Pietilä A-M, Saaranen T. Socio-demographic and work-related factors associated with the work ability of the unemployed. NES2016 - Ergonomics in Theory and Practice. Proceedings of 48th Annual Conference of Nordic Ergonomics and Human Factors Society; 2016. p. 70-4.

23. Szlachta E, Gawlik-Chmiel B, Kallus K. Do the long-term unemployed regard themselves as able to work? J Public Health. 2012;20:505-11.

24. Pensola T, Järvikoski A, Järvisalo J. Unemployment and work ability. In: Dimensions of Work Ability. Results of the Health 2000 Survey. In: Gould R, Ilmarinen J, Järvisalo J, Koskinen S, editors. National Public Health Institute, Finnish Institute of Occupational Health. Helsinki: Finnish Centre for Pensions, The Social Insurance Institution; 2008. p. 123-30.

25. IImarinen J. Work ability - a comprehensive concept for occupational health research and prevention. Scand J Work Environ Health. 2009;39(2):125-33.

26. Oivo T, Kerätär R. Osatyökykyisten reitit työllisyyteen -etuudet, palvelut, tukitoimet. [The paths of the partly disabled to employment - benefits, services and support]. Report 43. Helsinki: Ministry of Social Affairs and Health; 2018. Finnish. Available from: http://urn.fi/URN:ISBN:978-952-00-3997-4.

27. Kerätär R. You'll see more when you look from a distance. Multidimensional assessment of work ability and needs for rehabilitation among long-term unemployed. PhD thesis. Acta Universitatis Ouluensis D Medica 1340. 2016. Available from: http://urn.fi/urn:isbn:9789526210865.

28. Goud S, Fenger H. National report on the labour market position of vulnerable groups in the Netherlands. Rotterdam: Erasmus University; 2014. Available from: https://repub.eur.nl/pub/77323/Metis_204553.pdf.

29. Arnkil R, Spangar T, Jokinen E. Selvitys heikossa työmarkkina-asemassa olevien palveluista Pohjoismaissa sekä Alankomaissa, Iso-Britanniassa, Saksassa ja Ranskassa [Report on the available services for the population in a poor labour market situation in the Nordic countries and in the Netherlands, Great Britain, Germany and France]: Ministry of Employment and the Economy; 2012. Finnish. Available from: http://www.tem.fi/ julkaisut?C $=98033 \&$ \&mid $=4768$.

30. Hult M, Pietilä A-M, Saaranen T. Elämänlaadun ja elämän merkityksellisyyden kokemisen yhteydet työttömien työkykyyn [The perceived quality of life and relevance of life in relation to work ability of the unemployed]. Hoitotiede. 2017;29(2):78-88 Finnish

31. Kerätär R, Taanila A, Härkäpää K, Ala-Mursula L. Sairauslähtöisestä työ- ja toimintakyvyn arvioinnista monialaiseen arviointimalliin. [From a disease-based assessment assessment of work ability and functioning towards to a multidimensional assessment model]. Duodecim. 2014;130(5):495-502 Finnish.

32. Heponiemi T, Wahlström M, Elovainio M, Sinervo T, Aalto A, Keskimäki I. Katsaus työttömyyden ja terveyden välisiin yhteyksiin [An overview of the links between unemployment and health]. Helsinki: Ministry of Employment and the Economy; 2008. Finnish. Available from: https://docplayer.fi/195 0703-Katsaus-tyottomyyden-ja-terveyden-valisiin-yhteyksiin.html.

33. Lappalainen K. Supporting preparedness for work life among the unemployed - focus on health care and network communities. PhD thesis. University of Eastern Finland. 2017. Available from: http://urn.fi/URN:ISBN: 978-952-61-2452-0.

34. Kerätär R, Taanila A, Jokelainen J, Soukainen J, Ala-Mursula L. Work disabilities and unmet needs for health care and rehabilitation among jobseekers: a community-level investigation using multidimensional work ability assessments. Scand J Prim Health Care. 2016;34(4):343-51.

35. Anner J, Schwegler U, Kunz R, Trezzini de Boer W. Evaluation of work disability and the international classification of functioning, disability and health: what to expect and what not. BMC Public Health. 2012;12:470-8.

36. Björklund $O$, Söderlund $M$, Nyström L, Häggström E. Unemployment and Health: Experiences Narrated by Young Finnish Men. Am J Mens Health. 2015;9(1):76-85

37. Härkäpää K, Järvikoski A, Gould R. Motivational Orientation of People Participating in Vocational Rehabilitation. J Occup Rehab. 2014;24:658-69.

38. Finger M, Escorpizo R, Bostan C, De Bie R. Work Rehabilitation Questionnaire (WORQ): development and preliminary psychometric evidence of an ICFbased questionnaire for vocational rehabilitation. J Occup Rehabil. 2014; 24(3):498-510.

39. Tuomi K, Ilmarinen J, Jahkola M, Katajarinne L, Tulkki A. Työkykyindeksi [Work Ability Index]. Työterveyshuolto 19. Helsinki: Finnish Institute of Occupational Health; 1997. Finnish.

40. Rychetnik L, Frommer M, Hawe P, Shiell A. Criteria for evaluating evidence on public health interventions. J Epidemiol Community Health. 2002;56:119-27.

41. Coulter A. Measuring what matters to patients. OECD Health ministers commit to patient reported measures of performance. BMJ. 2017;356:1-2.

42. Finnish Institute for Health and Welfare (THL). The Finnish TOIMIA network: https://thl.fi/en/web/functioning. Accessed 11 Nov 2018. 
43. Unkila K, Lautala K, Wikström M, Joensuu M, Savinainen M. Kognitiivinen haastattelu kyselylomakkeen kehittämisessä. Esimerkkinä työ- ja toimintakyvyn itsearviointimenetelmä Kykyviisari [Cognitive interview in developing a questionnaire. As an example, the Abilitator a self-assessment questionnaire of work ability and functioning]. Kuntoutus. 2018;1:17-24 Finnish.

44. Tourangeau R. Cognitive sciences and survey methods. In: Jabine T, Straf M, Tanur J, Tourangeau R, editors. Cognitive Aspects of Survey Design. Building a Bridge Between the Disciplines. Washington: National Academy Press; 1984. p. 73-100.

45. Cieza A, Fayed N, Bickenbach J, Prodinger B. Refinements of the ICF Linking Rules to strengthen their potential for establishing comparability of health information. Disability and Rehabilitation; 2016. p. 1-10.

46. Bickenbach J, Cieza A, Rauch A, Stucki G, editors. ICF Core Sets: Manual for Clinical Practice. Göttingen: Hogrefe; 2012

47. Üstün T, Kostanjsek N, Chatterji S, Rehm J. Measuring Health and Disability: Manual for WHO Disability Assessment Schedule: WHODAS 2.0. Geneva: World Health Organization; 2010.

48. De Vet H, Terwee C, Mokkink L, Knol D. Measurement in Medicine. A Practical guide. Cambridge: University Press; 2011.

49. Mokkink L, Terwee C, Patrick D, Alonso J, Stratford P, Knol D, Bouter L, de Vet $\mathrm{H}$. The COSMIN study reached international consensus on taxonomy, terminology, and definitions of measurement properties for health-related patient-reported outcomes. J Clin Epidemiol. 2010;63:737-45.

50. Järvikoski A, Takala E-P, Juvonen-Posti P, Härkäpää K. The concept of work ability in the research and practice of rehabilitation. Social Insurance Institution of Finland. Social security and health reports, vol. 13; 2018. Available from: http://urn.fi/URN:NBN:fi-fe2018121050326.

51. Mäkitalo J, Palonen J. Mitä on työkyky: lääketieteellinen, tasapainomallin mukainen ja integroitu käsitystyyppi [What is work ability: biomedical, balance and integrative concepts]. Työ ja ihminen. 1994;8:155-62 Finnish.

52. Engel $\mathrm{G}$. The biopsychosocial model and the education of health professionals. Ann N Y Acad Sci. 1978;310(1):169-81.

53. Ilmarinen J, Tuomi K, Klockars M. Ikääntyminen ja työkykyindeksin muutokset: Työssä jatkaneiden seuranta tutkimus. Ikääntyvä työntekijä v. 1981-1992. Työn, elämäntyylin, terveyden ja työkyvyn muutokset [Ageing and changes in Work Ability Index]. Työ ja ihminen. 1995;9(2):95-117 Finnish.

54. Jensen A. Towards a parsimonious program theory of return to work intervention. Work. 2013:44(2):155-64.

55. Schultz I, Crook J, Frazer K, Joy P. Models of Return to Work for Musculoskeletal Disorders. J Occup Rehabil. 2007;17:327-52.

56. Svensson T, Mussener U, Alexanderson K. Pride, empowerment, and return to work: on the significance of promoting positive social emotions among sickness absentees. Work. 2006;27(1):57-65.

57. Franche $\mathrm{R}$, Krause N. Readiness for return to work following injury or illness: conceptualizing the interpersonal impact of health care, workplace, and insurance factors. J Occup Rehabil. 2002;12(4):233-56.

58. Engel $\mathrm{G}$. The need for a new medical model: a challenge for biomedicine. Science. 1977;196:129-36.

59. Jacobsson K, Seing I. En möjliggörande arbetsmarknadspolitik? Arbetsförmedlingens utredning och klassificering av klienters arbetsförmåga, anställbarhet och funktionshinder [An enabling labour market policy?] Arbetsmarknad Arbetsliv. 2013;19(1):9-24 Swedish.

60. McQuaid R, Lindsay C. The concept of employability. Urban Studies. 2005; 42(2):197-219.

61. Juvonen-Posti $P$, Joensuu M, Reiman A, Heusala T, Takala E-P. Työkykyjohtaminen - johdettua yhdessä tekemistä: Tapaustutkimus käytännön johtamismenettelyistä ja taloudellisesta vaikuttavuudesta kunnallisessa liikelaitoksessa [Work disability management]. Helsinki: Finnish Institute of Occupational Health; 2014. Finnish. Available from: http://www. julkari.fi/handle/10024/131550.

62. Mäkitalo J, Paso E. Työ, työ ja työ. Työlähtöinen työterveyshuolto ja kuntoutus [Work, work and work. Job-oriented occupational health care and rehabilitation]. Helsinki: Ministry of Social Affairs and Health; 2008. Finnish.

63. Seing I, Stahl C, Nordenfelt L, Bulow P, Ekberg K. Policy and practice of work ability: a negotiation of responsibility in organizing return to work. J Occup Rehabil. 2012;22(4):553-64.

64. World Health Organization (WHO). Towards a Common Language for Functioning, Disability and Health ICF. Geneva: WHO; 2002.

65. Üstun T, Chatterji S, Bickenbach J, Konstanisek N, Schneider M. The International Classification of Functioning. Disabil Health. 2003;25(11-12):565-71.
66. World Health Organization (WHO). WHO International Statistical Classification of Diseases and Related Health Problems 10th Revision. Volume 2, Instruction manual. Geneva: WHO; 2011.

67. World Health Organization (WHO). The ICD-10 classification of mental and behavioural disorders: clinical descriptions and diagnostic guidelines. Geneva: WHO; 1992

68. Madden R, Ferreira M, Einfeld S, Emerson E, Manga R, Refshauge K, Llewellyn G. New directions in health care and disability: the need for a shared understanding of human functioning. Aust N Z J Public Health. 2012;36(5):458-61.

69. IImarinen J, Tuomi K, Seitsamo J. New dimensions of work ability. Int Congress Ser. 2005;1280:3-7.

70. Ilmarinen J. Työurien pidentäminen ja työkyky [Longer working careers and work ability]. Työterveyslääkäri. 2016;34(4):23-9 Finnish.

71. Ilmarinen $V$, Ilmarinen J, Huuhtanen $P$, Louhevaara V, Näsman O. Examining the factorial structure, measurement invariance and convergent and discriminant validity of a novel self-report measure of work ability: work ability - personal radar. Ergonomics. 2015;58(8):1445-60.

72. Prodinger B, Cieza A, Oberhauser C, Bickenbach J, Üstün T, Chatterji S, Stucki G. Toward the International Classification of Functioning, Disability and Health (ICF) Rehabilitation Set: A Minimal Generic Set of Domains for Rehabilitation as a Health Strategy. Arch Phys Med Rehabil. 2016;97(6):875-84.

73. Wang T-J. Concept analysis of functional status. Int J Nurs Stud. 2004:41:457-62.

74. Arroll B, Khin N, Kerse N. Screening for depression in primary care with two verbally asked questions: cross sectional study. BMJ. 2003;327:1144-6.

75. The Abilitator questionnaire and user manual. Available from: www. kykyviisari.fi. Accessed 1 Aug 2019.

76. van den Berg T, Elders L, de Zwart B, Burdorf A. The effects of work-related and individual factors on the work ability index: A systematic review. Occup Environ Med. 2009;66:211-20.

77. PROMIS ${ }^{\circledast}$ Instrument Maturity Model http://www.healthmeasures.net/ explore-measurement-systems/promis. Accessed 3 Mar 2019.

78. Koponen P, Borodulin K, Lundqvist A, Sääksjärvi K, Koskinen S. Health, functional capacity and welfare in Finland - FinHealth 2017 study. Report 4. Helsinki: Finnish Institute for Health and Welfare; 2018.

79. Koskinen S, Lundqvist A, Ristiluoma N. Health, functional capacity and welfare in Finland in 2011. Report 68. Helsinki: Finnish Institute for Health and Welfare; 2012.

80. Kurvinen A, Jolkkonen A. Työllisyyden voimavarat mittari [Resources for employment questionnaire]. Report 3. Spatia:2015. Finnish. Available from: www.uef.fi/spatia.

81. Punakallio A, Lusa S. Eri-ikäisten palomiesten terveys- ja toimintakyky: 13vuoden seurantatutkimus [Health, physical and mental capacity of firefighters in different age groups: a 13-year follow-up]. Helsinki: Finnish Institute of Occupational Health; 2011. Finnish. Available from: https://www. julkari.fi/handle/10024/134824.

82. WORK ABILITY INDEX ${ }^{\mathrm{T} M}$. Helsinki: Finnish Institute of Occupational Health; 2014 www.ttl.pikakirjakauppa.fi/tuoteryhma/publications_in_english/17543 80\#!product_id=TTLWAl. Accessed 1 Aug 2018.

83. Townsend P. The Family Life of Old People. London: Routledge and Kegan Paul; 1957.

84. Elo A-L, Leppänen A, Lindström K. OSQ: Occupational stress questionnaire: Urser's instructions. Reviews 19. Helsinki: Finnish Institute of Occupational Health; 1992.

85. Kaikkonen R, Murto J, Pentala O, Koskela T, Virtala E, Härkänen T, Koskenniemi T, Ahonen J, Vartiainen E, Koskinen S. Alueellisen terveys- ja hyvinvointitutkimuksen perustulokset 2010-2014 [The Finnish Regional Health and Well-being Study; baseline results]. Helsinki: Finnish Institute for Health and Welfare; 2014. Finnish. Available from: www.thl.fi/ath.

86. Tennant R, Hiller L, Fishwick R, Platt S, Joseph S, Weich S, Parkinson J, Secker J, Stewart-Brown S. The Warwich-Edinburgh Mental Well-Being Scale (WEMWBS): development and UK validation. Health Qual Life Outcomes. 2007;5:63.

87. Aromaa A, Koskinen S. Health and functional capacity in Finland. Baseline results of the Health 2000 health examination survey. Report B3. Helsinki: National Public Health Institute; 2002. Available from: http://urn.fi/URN:NBN: fi-fe201204193452.

88. Kirves K. Perceived employability: Antecedents, trajectories and well-being consequences. PhD thesis. University of Tampere. 2014. Available from: http://urn.fi/URN:ISBN:978-951-44-9428-4.

\section{Publisher's Note}

Springer Nature remains neutral with regard to jurisdictional claims in published maps and institutional affiliations. 